\title{
Mycoplasma pneumoniae AND Chlamydia pneumoniae IN CALCIFIED NODULES OF AORTIC STENOTIC VALVES
}

\author{
Maria de Lourdes HIGUCHI, Marilia Harumi HIGUCHI-DOS-SANTOS, Humberto PIERRI, Sueli PALOMINO, Nadia Vieira SAMBIASE, \\ José Antonio Franchini RAMIRES \& Maurício WAJNGARTEN
}

\begin{abstract}
SUMMARY
Aortic Valve Stenosis (AVS) has been explained as an atherosclerotic process of the valve as they often exhibit inflammatory changes with infiltration of macrophages, $\mathrm{T}$ lymphocytes and lipid infiltration. The present study investigated whether the bacteria Chlamydia pneumoniae (CP) and Mycoplasma pneumoniae (MP), detected previously in atherosclerotic plaques, are also present in AVS. Ten valves surgically removed from patients with AVS were analyzed by immunohistochemistry, in situ hybridization, and electron microscopy. The mean and standard deviation of the percentage areas occupied by CP antigens and MP - DNA were respectively $6.21+/-5.41$ and $2.27+/-2.06$ in calcified foci; $2.8+/-3.33$ and $1.78+/-3.63$ in surrounding fibrotic areas, and $0.21+/-0.17$ and 0.12 $+/-0.13$ in less injured parts of the valve. There was higher amount of CP and MP in the calcified foci and in the surrounded fibrosis than in more preserved valvular regions. In conclusion, the fact that there were greater amounts of CP and MP in calcification foci of AVS favors the hypothesis that AS is not an inevitable degenerative process due to aging, but rather that it may be a response to the presence of these bacteria, similarly to the morphology detected in atherosclerosis damage.
\end{abstract}

KEYWORDS: Mycoplasma pneumoniae; Chlamydia pneumoniae; Aortic Valve; Calcification; Atherosclerosis.

\section{INTRODUCTION}

Age-related degenerative calcified aortic valve stenosis is now the most frequent cause of AVS in adults, frequently requiring aortic valve replacement ${ }^{13}$. It is usually considered to result from years of normal mechanical stress on a valve. Some studies have suggested that it would be similar a process to arterial atherosclerosis, as these valves often exhibit infiltration of macrophages and $\mathrm{T}$ lymphocytes nearby the calcified nodules $^{12,14}$. Hypercholesterolemia seems to accelerate age-related degenerative changes in the aortic root and valve ${ }^{15}$, and traditional risk factors for atherosclerosis such as cigarette smoking, history of hypertension, and low high-density-lipoprotein (HDL) cholesterol values are also related to calcified $\mathrm{AVS}^{18}$.

Chlamydia pneumoniae $(\mathrm{CP})$ seems to be involved in atherosclerotic process pathogenesis ${ }^{4,19}$. This bacterium has also been detected in vascular tissues and degenerative heart valves ${ }^{4,9}$.

Recent studies from our Lab have detected large amounts of Mycoplasma pneumoniae (MP) and CP in ruptured coronary atherosclerotic plaques, which were also accompanied by increased number of lymphocytes ${ }^{6,7,8}$. The present study investigated whether MP and $\mathrm{CP}$ were present in AVS valves, in association with calcification foci and inflammation, as noticed in atherosclerotic plaques.

\section{MATERIALS AND METHODS}

Ten aortic valves surgically removed from AS patients, fixed in $10 \%$ formalin, decalcified in formic acid $25 \%$ and embedded in paraffin were sectioned in $5 \mu \mathrm{m}$ slices and submitted to immunohistochemical (IHC) technique for detection of $\mathrm{CP}$ and in situ hybridization technique for detection of MP and CP. Representative transversal sections of the most calcified cuspid were analyzed, separated in three different regions: A) Calcified nodules, B) Fibrosis surrounding the calcified nodules, and C) Most preserved region of the valve.

Quantification of CP antigens and MP DNA was performed with image analysis system Quantimet 500 - Leica, using 20x magnification objective. All fields presented in the section were analyzed. It was obtained mean values of $\%$ area of CP antigens and \% area of MP DNA / 200x microscopic field.

Representative fragments were also collected for electron microscopy analysis.

For immunohistochemistry the slides were incubated with pure monoclonal anti-CP antibody (clone RR-402, Dako, Carpinteria, CA, USA, anti-major outer external membrane of $\mathrm{CP}$ ), according to previously described technique ${ }^{6}$. 

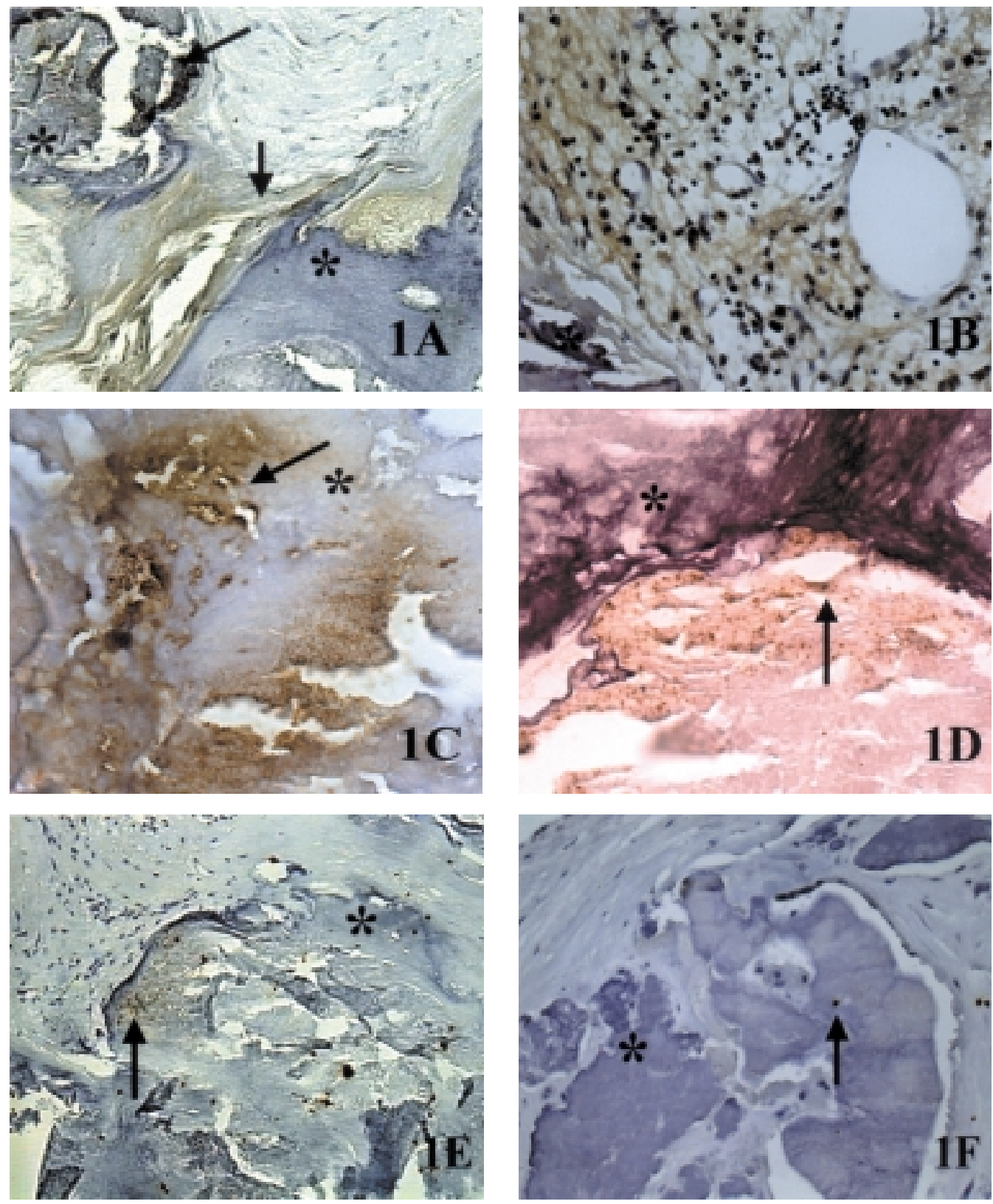

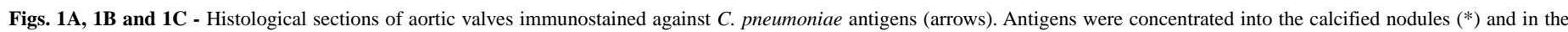

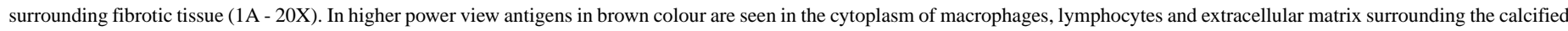

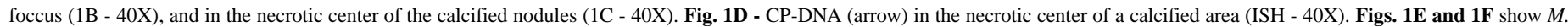
pneumoniae-DNA (arrows), detected by ISH, in calcified foci, usually abundant (1E - 40X) but scarce in old foci (1F - 20X).

For in situ hybridization, it was used the technique described in a previous paper $^{7}$ and summarized below. For MPDNA detection the slides were incubated with $20 \mu \mathrm{l}$ of hybridization mixture containing the probe prepared from a highly specific MP clone (Enzo Diagnosis, Farmingdale, NY, USA). For detection of CPDNA the probe was the biotinylated labeled CP oligonucleotide synthesise by GIBCO/ BRL, Rockville, MD, USA. The signal was amplified using the catalyzed signal amplification system for ISH, Dakogen Point (Dako, Carpinteria, CA, USA). The reaction was visualized with the chromogen 3,3diaminobenzidine (Dako, Carpinteria, CA, USA).
Positive controls of immunohistochemistry and in situ hybridization techniques were performed using rats and rabbits respectively infected with Chlamydia pneumoniae and Mycoplasma pneumoniae. These animals had positive diagnosis of these infectious agents by culture.

For electron microscopy, the tissue was decalcified in tri-chloroacetic acid $5 \%$, fixed in $3 \%$ glutaraldehyde $0.1 \mathrm{M}$, post-fixed with $1 \%$ osmium tetroxide and blocked in araldite resin ${ }^{17}$. 


\section{RESULTS}

$\mathrm{CP}$ antigens were present in the calcified nodules and in their surrounded fibrotic tissue in a diffuse and homogeneous pattern (Fig. 1A). In the periphery of these nodules, there was moderate to severe inflammatory infiltrate with several macrophages containing positive granules (brown color) or homogeneous pattern in the cytoplasm or as positive dots in the extracellular matrix (Fig. 1B). Dots were also seen in calcified nodules (Fig. 1C). The in situ hybridization technique demonstrated CP-DNA mainly at the periphery of the calcified foci (Fig. 1D). The mean and standard deviations of $\mathrm{CP}$ antigens percentage areas were $6.21 \pm 5.41$ in calcified areas; $2.8 \pm 3.33$ in surrounding fibrotic areas; and $0.21 \pm 0.17$ in preserved areas.

MP-DNA was seen as brown dots concentrated in the calcified foci, mainly in those surrounded by inflammatory infiltrate (Fig. 1E). Older calcified foci, which were characterized as surrounded by dense acellular fibrosis without inflammatory infiltrate, were almost negative for MPDNA (Fig. 1F). The mean \% areas of MP-DNA were $2.27 \pm 2.06$ in calcified areas; $1.78 \pm 3.3$ in fibrotic areas; and $0.12 \pm 0.13$ in preserved areas of the valve.

There was a significantly higher amount of MP and CP in the calcified nodules than in more preserved areas (Student T paired test $=p<0.05$ ). $\mathrm{CP}$ antigen concentration in the calcified nodules was also significantly higher than in the fibrotic surrounding tissue $(\mathrm{p}<0.05)$.

Electron microscopy also demonstrated great amount of round small structures compatible with bacteria in the calcified areas. Most of them were dark, round, involved by two membranes, frequently exhibiting an expansion of the external membrane, characterizing CP elementary bodies (Fig. 2A); as their limits and membranes were not very well defined, they were considered as degradation of the bacteria. Less electron-dense granulous and rounded elements, involved by a membrane compatible with mycoplasma, were detected in smaller amounts (Fig. 2A). In the tissues adjacent to the calcified foci, the bacteria had better preserved membranes. Many empty membranous structures suggestive of bacteria debris (Fig. 2B) were seen.

\section{DISCUSSION}

Some similarities between atherosclerosis of the valve and AVS, such as chronic inflammation with macrophages and $\mathrm{T}$ lymphocytes, have been described ${ }^{10,11,12}$. In the present study, it was observed that calcified nodules of AS valves present high concentration of CP and MP, detected by in situ hybridization, immunohistochemistry and electron microscopy. The fibrotic tissue surrounding the calcified foci presented high amount of CP antigens. Culture for detection of mycoplasmas was not used because these are bacteria that grow very well when in contact with host cells, but hardly ever grow in culture media. Mycoplasmas are the smallest and simplest self-replicating bacteria and the only bacteria that use cholesterol for proliferation. Macrophage activation, cytokine induction and superantigen formation are properties related with the pathogenicity of mycoplasma and they increase virulence of other contiguous infectious agents $^{16}$.

Dystrophic calcification is found in foci of enzymatic necrosis of fat. Calcification is present in most advanced atheromas and damaged ageing heart valves. The presence of great amount of membrane degenerated $\mathrm{CP}$ and MP is the appropriate substrate to favor deposition of calcium.

Extracellular dystrophic calcification occurs in the presence of phospholipids found in 200- $\eta \mathrm{m}$ membrane-bound vesicles in the cartilage and bone and in pathologic calcification. Calcification has several steps: (1) Calcium ion binds to the phospholipids of the vesicle membranes; (2) membrane phosphatase generates phosphate groups, which bind to calcium; (3) the binding cycle of calcium and phosphatase is repeated, producing a deposit near the membrane; and (4) a structural change occurs in the arrangement of calcium and phosphate groups generating a microcrystal, which can then propagate and perforate the membrane ${ }^{3}$. CP actively participates in the destruction of the extracellular matrix, by regulating the expression of some enzymes such as $92-\mathrm{kDa}$ gelatinase by macrophages ${ }^{20}$. The results of the present study may indicate that calcified foci in AVS represent severe proliferation of MP and CP and the fibrosis surrounding them could be a host defense response to circumscribe these infectious agents. It is not expectable to find great amounts of mycoplasmas amidst fibrosis, as they do not survive among dense hard collagen because of lack cholesterol. Some CP may survive, because as it was already mentioned, they can digest the extracellular matrix. Differently from other bacteria that usually cause acute infectious endocarditis inciting neutrophilic inflammation, the present bacteria cause insidious, chronic inflammation that culminates with fibrosis and calcification of the valves.

Recent data pointed to an association between AVS and systemic atherosclerosis and inflammation. These include association with symptomatic peripheral arterial disease in the elderly ${ }^{1}$, coronary artery disease $^{2}$ and increased C-reactive protein ${ }^{5}$. In our view, AVS could be a sequel of a chronic infectious injury, which is in accordance with the findings just described.

Further studies analyzing the occurrence of these bacteria in noncalcified valves are necessary in order to better clarify why these bacteria proliferate only in some patients, leading to development of AVS.

In conclusion, calcification foci in AVS contain large amounts of mostly degenerated Chlamydia pneumoniae and Mycoplasma pneumoniae bacteria. This finding suggests that AVS is not an inevitable degenerative process due to ageing, but rather that it may be a response to the presence of these bacteria, whose morphology is similar to that of atherosclerosis damage.

\section{RESUMO}

\section{Mycoplasma pneumoniae e Chlamydia pneumoniae nos focos de calcificação de valva aórtica estenótica}

Estenose da Valva Aórtica (EVA) tem sido considerada como um processo aterosclerótico das valvas pois elas freqüentemente exibem alterações inflamatórias com acúmulo de macrófagos e linfócitos T, bem como infiltração de lípides. O presente estudo investigou se as bactérias Chlamydia pneumoniae (CP) e Mycoplasma pneumoniae (MP), detectadas previamente em placas ateroscleróticas, estavam presentes na EVA. Dez valvas removidas cirúrgicamente de pacientes com EVA foram analisadas pela imunohistoquímica, hibridização in situ e microscopia eletrônica. A média e desvio padrão das porcentagens de área ocupadas por antígenos de CP e de DNA do MP foram 


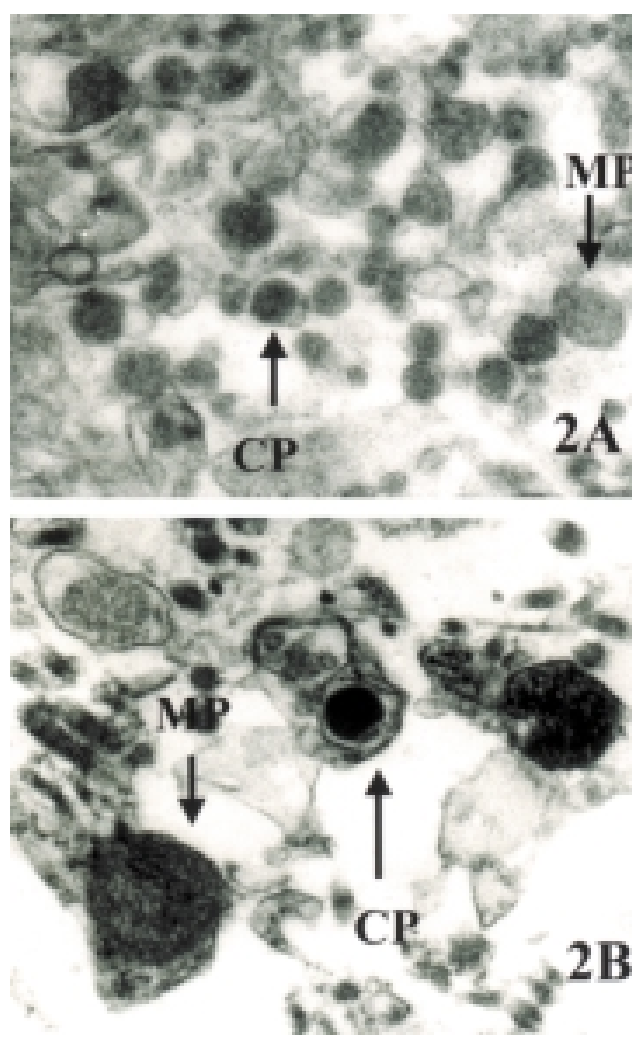

Figs. 2A and 2B - Electron microscopic views of aortic stenotic valve. Fig. 2A shows great amount of CP - Chlamydia pneumoniae elementary bodies with the characteristic "pear shape" and MP - Mycoplasma pneumoniae - involved by one membrane, in a focus of calcification (- 13,000 X - original magnification). Fig. 2B demonstrates MP and CP with better preserved membranes among the inflammatory infiltrate adjacent the calcification (7,200 X - original magnification).

respectivamente de 6,21 +/- 5,41 e 2,27 +/-2,06 nos focos de calcificação; 2,8 +/- 3,33 e 1,78+/- 3,063 nas áreas de fibrose ao redor e 0,21 +/- 0,17 e $0,12+/-0,13$ nas regiões menos lesadas da válvula. Houve uma maior quantidade de CP e MP nos focos de calcificação e na fibrose ao redor do que nas regiões valvulares mais preservadas. Em conclusão, o fato de haver maior quantidade de CP e MP nos focos de calcificação da EVA favorece a hipótese de que a estenose aórtica não é um processo degenerativo inevitável devido a idade, mas sim uma resposta inflamatória à presença dessas bactérias, em uma morfologia semelhante à detectada na injúria aterosclerótica.

\section{ACKNOWLEDGMENT}

This study was financially supported by FAPESP (Project No. 99/ 00322-9 and 00/06974-7).

\section{REFERENCES}

1. ARONOW, W. S.; AHN, C. \& KRONZON, I. - Association of valvular aortic stenosis with symptomatic peripheral arterial disease in older persons. Amer. J. Cardiol., 88: 1046-1047, 2001

2. AVAKIAN, S.D.; GRINBERG, M.; MENEGUETTI, J.C.; RAMIRES, J.A. \& MANSUR, A.P. - SPECT dipyridamole scintigraphy for detecting coronary artery disease in patients with isolated severe aortic stenosis. Int. J. Cardiol., 81: 21-27, 2001.
3. COTRAN, R.S.; KUMAR, V. \& COLLINS, T. - Cellular Pathology. II: adaptations, intracellular accumulations, and cell aging. In: COTRAN, R.S.; KUMAR, V. \& COLLINS, T., ed. Robbins pathologic basis of disease. 6. ed. Philadelphia, W.B. Saunders, 1999. p. 43-44.

4. DANESH, J.; COLLINS, R. \& PETO, R. - Chronic infections and coronary heart disease: is there a link? Lancet, 350: 430-436, 1997.

5. GALANTE, A.; PIETROIUSTI, A.; VELLINI, M. et al. - C-reactive protein is increased in patients with degenerative aortic valvular stenosis. J. Amer. Coll. Cardiol., 142. 725-732, 2001

6. HIGUCHI, M.L.; CASTELLI, J.B.; AIELLO, V.D. et al. - Great amount of Chlamydia pneumoniae in ruptured plaque vessel segments at autopsy. A comparative study of stable plaques. Arq. bras. Cardiol., 74: 149-151, 2000.

7. HIGUCHI, M.L.; SAMBIASE, N.; PALOMINO, S. et al. - Detection of Mycoplasma pneumoniae and Chlamydia pneumoniae in ruptured atherosclerotic plaques. Braz. J. med. biol. Res., 33: 1023-1026, 2000.

8. HIGUCHI, M.L.; GUTIERREZ, P.S.; BEZERRA, H.G. et al. - Comparison between adventitial and intimal inflammation of ruptured and nonruptured atherosclerotic plaques in human coronary arteries. Arq. bras. Cardiol., 79: 20-24, 2002.

9. JUVONEN, J.; LAURILA, A.; JUVONEN, T. et al. - Detection of Chlamydia pneumoniae in human nonrheumatic stenotic aortic valves. J. Amer. Coll. Cardiol., 29: 1054$1059,1997$.

10. OLSSON, M.; DALSGAARD, C.J.; HAEGERSTRAND, A. et al. - Accumulation of T lymphocytes and expression of interleukin-2 receptors in nonrheumatic stenotic aortic valves. J. Amer. Coll. Cardiol., 23: 1162-1170, 1994.

11. OLSSON, M.; ROSENQVIST, M. \& NILSSON, J. - Expression of HLA-DR antigen and smooth muscle cell differentiation markers by valvular fibroblasts in degenerative aortic stenosis. J. Amer. Coll. Cardiol., 24: 1664-1671, 1994.

12. OTTO, C.M.; KUUSISTO, J.; REICHENBACH, D.D.; GOWN, A.M. \& O'BRIAN, K.D. - Characterization of the early lesion of 'degenerative' aortic stenosis. Histological and immunohistochemical studies. Circulation, 90: 844-853, 1994.

13. OTTO, C.M.; LIND, B.K.; KITZMAN, D.W.; GERSH, B.J. \& SISCOVICK, D.S. Association of aortic-valve sclerosis with cardiovascular mortality and morbidity in the elderly. New Engl. J. Med., 341: 142, 1999.

14. POHLE, K.; MÄFFERT, R.; ROPERS, D. et al. - Progression of aortic valve calcification: association with coronary atherosclerosis and cardiovascular risk factors. Circulation, 104: 1927-1932, 2001.

15. RALLIDIS, L.; NAOUMOVA, R.P.; THOMPSON, G.R. \& NIHOYANNOPOULOS, P. - Extent and severity of atherosclerotic involvement of the aortic valve and root in familial hypercholesterolaemia. Heart, 80: 583-590, 1998.

16. RAZIN, S.; YOGEV, D. \& NAYOT, Y. - Molecular biology and pathogenicity of mycoplasmas. Microbiol. molec. Biol. Rev., 62:1094-1156, 1998.

17. REYNOLDS, E. S. - The use of lead citrate at high $\mathrm{pH}$ as an electron-opaque stain in electron microscope. J. Cell Biol., 17: 208-212, 1963.

18. STEWART, B.F.; SISCOVICK, D.; LIND, B.K. et al - Clinical factors associated with calcified aortic valve disease. J. Amer. Coll. Cardiol., 29: 630-634, 1997.

19. TAYLOR-ROBINSON, D. \& THOMAS, B.J. - Chlamydia pneumoniae in arteries: the facts, their interpretation, and studies. J. clin. Path., 51: 793-797, 1998.

20. VEHMAAN-KREULA, P.; PUOLAKKAINEN, M.; SARVAS, M. et al. - Chlamydia pneumoniae proteins induce secretion of the $92-\mathrm{kDa}$ gelatinase by human monocytederived macrophages. Arterioscler. Thromb. vasc. Biol., 21: E1-E8, 2001.

Received: 13 May 2002

Accepted: 28 June 2002 